\title{
Isolation of Streptomycin-Resistant Isolates of Erwinia amylovora in New York
}

\author{
Nicole L. Russo and Thomas J. Burr, Department of Plant Pathology, Cornell University, Geneva, NY 14456; \\ Deborah I. Breth, Cornell Cooperative Extension, Albion, NY 14411; and Herb S. Aldwinckle, Department of \\ Plant Pathology, Cornell University
}

\begin{abstract}
Russo, N. L., Burr, T. J., Breth, D. I., and Aldwinckle, H. S. 2008. Isolation of streptomycinresistant isolates of Erwinia amylovora in New York. Plant Dis. 92:714-718.

Streptomycin is currently the only antibiotic registered for the control of fire blight, a devastating disease of apple (Malus), pear (Pyrus), and other rosaceous plants caused by the bacterium Erwinia amylovora. Resistance of E. amylovora to streptomycin was first identified in California pear orchards in 1971 and is currently endemic in many parts of the United States. The Northeast remains the only major U.S. apple-growing region without streptomycin-resistant isolates of $E$. amylovora. In 2002, during a routine survey for streptomycin resistance, isolates from two neighboring orchards in Wayne County, NY were found to be highly resistant to streptomycin at a concentration of $100 \mu \mathrm{g} / \mathrm{ml}$. This constitutes the first authenticated report of streptomycin resistance in New York State. Infected trees were shipped at the same time from a single nursery in Michigan. Resistance was caused by the acquisition of the $\operatorname{str} A-s \operatorname{tr} B$ gene pair, inserted into the ubiquitous nontransmissible E. amylovora plasmid pEA29. Previously, streptomycin-resistant $E$. amylovora populations from Michigan were described with a similar mechanism of resistance, although the strA-strB genes are not unique to Michigan. These findings illustrate how unintentional movement of nursery material could undermine efforts to prevent the spread of antibioticresistant E. amylovora.
\end{abstract}

Additional keywords: antibiotic resistance

Fire blight, caused by the Enterobacterium Erwinia amylovora (Burrill) Winslow et al., is a devastating disease of rosaceous plants. Most commonly occurring on apple (Malus spp.) and pear (Pyrus spp.), fire blight affects production of these fruit in over 40 countries (4). Fire blight occurs in three distinct phases: blossom blight, shoot blight, and rootstock blight. Of these, blossom blight, the infection of newly opened blossoms, is the most significant, resulting in devastating crop losses (40) while serving as a precursor to the shoot and rootstock phases of the disease, either of which can be fatal to trees (29). Blossom blight is also the sole phase of fire blight with a prediction system and effective chemical control (4).

Blossom blight is controlled primarily through application of the aminoglycoside antibiotic streptomycin, which was introduced as a pesticide for horticultural use in 1955 (23,25). Although streptomycin was highly effective, streptomycin-resistant isolates of E. amylovora were identified in California pear orchards in 1971 (24) and soon after in Washington and Oregon, in

Corresponding author: H. S. Aldwinckle

E-mail: hsa1@cornell.edu

Accepted for publication 13 December 2007.

doi:10.1094/PDIS-92-5-0714

(C) 2008 The American Phytopathological Society
1972 (11,20). Streptomycin resistance has been reported throughout the major pomefruit production areas in the western United States as well as in Michigan, Missouri, British Columbia (Canada), Israel, Lebanon, and New Zealand $(11,23,34$, 35,39).

Two mechanisms of streptomycin resistance have been described in E. amylovora. The more common form of resistance occurs through a single base-pair mutation of the streptomycin-binding site. Streptomycin binds to protein S12 of the 30S ribosomal subunit, encoded by the rpsL gene, thereby preventing protein synthesis (23). Chiou and Jones (10) determined that streptomycin resistance was caused by a single base-pair mutation in codon 43 of the rpsL gene (10). Mutational resistance is highly stable and has been shown to persist in the environment in the absence of selection pressure. Moller et al. (25) reported that streptomycin-resistant populations of E. amylovora could still be detected in California pear orchards 10 years after the application of streptomycin had ceased.

Streptomycin resistance has also been attributed to the acquisition of resistance plasmids, which confer enzyme-mediated resistance. Chiou and Jones (7) established that streptomycin resistance in Michigan E. amylovora populations was based on the acquisition of the plasmid pEa34, which possesses the $\operatorname{str} A-s t r B$ gene cluster. Plasmid pEa34, a conjugative plasmid, likely originated in Pantoea agglomerans and was acquired by E. amylovora through conjugal transfer $(7,22)$. The tandem strA$s t r B$ genes code for aminoglycoside-3phosphotransferase and aminoglycoside-6phosphotransferase, respectively (9). These aminoglycoside-modifying enzymes modify streptomycin, and previously have been described in resistant populations of Pseudomonas syringae pv. papulans, $P$. syringae pv. syringae, and Xanthomonas campestris pv. campestris $(17,23,38)$, as well as some bacteria of human and animal origin (22). Although the $\operatorname{str} A$ and $\operatorname{str} B$ genes function independently, both must be present to confer high levels of antibiotic resistance (9). The strA-strB genes have been found on broad host range plasmids such as pRSF1010 (pEa8.7) (30) or located within the transposable element Tn5393 inserted into strain-specific plasmids like pEa34 (8). Tn5393, with strA$\operatorname{str} B$, also has been discovered inserted into the nontransmissible $E$. amylovora plasmid pEA29 and into the chromosome (22). These mobilizable resistance genes have previously been identified in common epiphytic bacteria found in orchards $(5,6,13$, 28,37).

Currently, the Northeast is the only major apple production region in the United States without endemic populations of streptomycin-resistant E. amylovora. Resistance surveys conducted by Beer and Norelli (1) and Burr et al. $(5,6)$ failed to identify streptomycin-resistant populations of E. amylovora between 1975 and 1992. However, Burr et al. $(5,6)$ did confirm the presence of the streptomycin resistance genes, strA-strB, in orchard populations of the blister spot pathogen $P$. syringae pv. papulans, often associated with fire blight. Orchard surveys in New York are separated by many years, at which time resistant populations could become established, thereby limiting the effectiveness of eradication measures. The objectives of this study were to survey orchards throughout New York for the presence of streptomycinresistant isolates of E. amylovora and to characterize resistance if found.

\section{MATERIALS AND METHODS}

Orchard survey. Active fire blight lesions were collected by regional Cornell Cooperative Extension Associates and by Dr. David A. Rosenberger of Cornell University's Hudson Valley Laboratory, and processed at the New York State Agricultural Experiment Station in Geneva from 
2002 through 2006. Sampling sites were chosen based on past streptomycin use and reports of inconsistency in control of fire blight using streptomycin. Fire blight lesions were collected in 14 counties from 56 individual farm sites. Samples primarily consisted of infected shoot tissue, although fruit and rootstock tissues were sampled when applicable. An average of three isolations from three different infected tissues were made from each submitted sample.

Isolation of bacteria and resistance screening. Single-colony isolates of $E$. amylovora were isolated from infected tissue and tested for antibiotic resistance according to Burr et al. (5). Samples were surface sterilized in $0.5 \%$ sodium hypochlorite solution for $10 \mathrm{~min}$ and rinsed with sterile distilled water. Outer bark was removed and internal tissue plated on Crosse and Goodman (CG) medium (12), diagnostic for Erwinia spp. Single-colony isolates were identified as E. amylovora by colony morphology. Final confirmation was based on the presence of a 1-kb fragment amplified from the ubiquitous $E$. amylovora plasmid pEA29, modified from Bereswill et al. (2). Polymerase chain reactions (PCRs), $50 \mu \mathrm{l}$ in total volume, were carried out using $2.5 \mu \mathrm{M}$ primers A and B (2), $12.5 \mathrm{mM} \mathrm{MgCl}_{2}, 5 \mu \mathrm{l}$ of PCR Reaction Buffer (Promega Corp., Madison, WI), 0.1 $\mathrm{mM}$ dNTPs, 0.625 units of Taq DNA Polymerase (Promega Corp.), and $10 \mu \mathrm{l}$ of bacterial sample, and PCR products were analyzed by electrophoresis using $1 \%$ agarose gels. Three colonies, when possible, were stored from each sample for resistance screening.

To assess the level of streptomycin resistance, isolates were grown at $28^{\circ} \mathrm{C}$ in $5 \mathrm{ml}$ of liquid Luria-Bertani (LB) broth and $100-\mu$ l aliquots, adjusted to $10^{8} \mathrm{CFU} / \mathrm{ml}$, were spread evenly on LB medium. Bacteria were challenged with filter paper disks (Schleicher \& Schuell Inc., Keene, NH) impregnated with a solution of streptomycin sulfate at $0,10,50$, or $100 \mu \mathrm{g} / \mathrm{ml}$ and incubated at $28^{\circ} \mathrm{C}$. Resistance levels were determined by measuring the clear zone of inhibition assessed at 24 and $48 \mathrm{~h}$. Three replicated plates of each single-colony isolate were evaluated for resistance; experiments were repeated to verify results. Resistance level was compared against the streptomycin-susceptible strain Ea273, described by Norelli et al. (27), and the streptomycin-resistant strain CFBP1376str, a streptomycin-resistant variant of strain CFBP1376 originally characterized by Paulin and Samson (31).

Bacterial isolates and plasmid selection. E. amylovora isolates CA11 (8) and BCN77 (22), containing the strA-strB gene pair, and strain Ea110- , containing plasmid pC9, were provided by Dr. George Sundin and Gayle McGhee at Michigan State University (21; Table 1). NY17.1 and NY17.2 are the uncharacterized streptomycin- resistant isolates of E. amylovora that originated from this study.

Pathogenicity assays. Bacteria that displayed resistance to streptomycin were assessed for pathogenicity using both immature green pear fruit (3) and seedling inoculation tests (32). Cross-sections, 5 $\mathrm{mm}$ thick, of immature pear fruit were wounded with toothpicks dipped in inoculum and incubated overnight at $28^{\circ} \mathrm{C}$ for $48 \mathrm{~h}$. Isolates were recorded as pathogenic if the inoculation site became necrotic and ooze exuded from the wound. Actively growing McIntosh seedlings, approximately $10 \mathrm{~cm}$ in height, were inoculated by transversely bisecting the two youngest leaves with scissors dipped in a suspension of streptomycin-resistant isolates NY17.1 and NY17.2 $\left(1 \times 10^{7} \mathrm{CFU} / \mathrm{ml}\right)$ in $0.5 \mathrm{M}$ potassium phosphate buffer according to Norelli et al. (27). Necrotic lesions accompanied by the production of bacterial ooze confirmed pathogenicity on apple seedlings. Results were compared against the susceptible strain Ea273 and resistant strain CFBP1376str.

Sequencing of the ribosomal protein S12 (rpsL) gene. An internal region of the ribosomal rpsL gene, containing codon 43, was amplified from streptomycin-resistant New York isolates NY17.1, and NY17.2, along with streptomycin-resistant isolates CA11, Ea88-100, and CFBP1376str and a streptomycin-sensitive strain Ea273. Primers were based on the rps $L$ gene sequence from E. amylovora (GenBank accession number L 36465; Table 2). PCR reactions, $50 \mu \mathrm{l}$ in total volume, were carried out using $0.4 \mu \mathrm{M}$ primers rpsL212F and rpsL212R, $12.5 \mathrm{mM} \mathrm{MgCl}_{2}, 5 \mu \mathrm{l}$ of PCR Reaction Buffer (Promega Corp.), $0.1 \mathrm{mM}$ dNTP, 0.625 units of Taq DNA Polymerase (Promega Corp.), and $10 \mu \mathrm{l}$ of bacterial sample, and PCR products were analyzed by electrophoresis using $1 \%$ agarose gels. PCR products were purified using Wizard SV Gel and PCR Clean-Up System (Promega Corp.). Samples were sequenced using an Applied Biosystems Automated 3730 DNA Analyzer (Foster City, CA) at the Core Laboratories Center (CLC; Ithaca, NY).

strA-strB gene identification. Internal regions of the strA and $\operatorname{str} B$ genes were amplified from New York isolates NY17.1 and NY17.2, along with streptomycinresistant E. amylovora isolates CA11 and CFBP1376str and streptomycin-sensitive strain Ea273. Primers were based on the $E$. amylovora strA and $s t r B$ gene sequences characterized by Chiou and Jones (8; GenBank accession number M 96392; Table 2). PCR reactions, $50 \mu \mathrm{l}$ in total volume, were carried out using $0.4 \mu \mathrm{M}$ either strA406-f and strA406-r or strB403$\mathrm{f}$ and strB403-r primers, $12.5 \mathrm{mM} \mathrm{MgCl}_{2}$, $5 \mu \mathrm{l}$ PCR Reaction Buffer (Promega Corp.), $0.1 \mathrm{mM}$ dNTP, 0.625 units of Taq DNA Polymerase (Promega Corp.), and 10 $\mu \mathrm{l}$ of bacterial sample, and PCR products were analyzed by electrophoresis using $1 \%$ agarose gels. PCR products were purified using Wizard SV Gel and PCR Clean-Up System (Promega Corp.). Samples were sequenced using an Applied Biosystems Automated 3730 DNA Analyzer at the CLC to verify gene identity.

Plasmid transfer. Plasmid transfer rates were determined according to Chiou and Jones (7). Recipient bacteria were rifampicin-resistant mutants of E. amylovora strain Ea273 identified as CU0380. An equal number of cells of recipient strain CU0380 were mixed with each of the donor isolates NY17.1, NY17.2, CA11, and Ea273. Mixtures were incubated overnight

Table 1. Bacterial isolates and plasmids

\begin{tabular}{|c|c|c|}
\hline Strain, plasmid & Relevant characteristics $^{\mathbf{a}}$ & $\begin{array}{l}\text { Source or } \\
\text { reference }\end{array}$ \\
\hline \multicolumn{3}{|c|}{ Erwinia amylovora } \\
\hline $\mathrm{Ea} 273$ & Ubiquitous plasmid pEA29, [ATCC 49946] & 27 \\
\hline CU0380 & $\mathrm{Rf}^{\mathrm{r}}$ variant of Ea273, mutational resistance & S. Beer ${ }^{b}$ \\
\hline CFBP1376str & $\mathrm{Sm}^{\mathrm{r}}$ variant of CFBP1376, mutational resistance & 31 \\
\hline Ea88-100 & $\mathrm{Sm}^{\mathrm{r}}$, mutational resistance & 20 \\
\hline CA11 & $\mathrm{Sm}^{\mathrm{r}}, \mathrm{pEa} 34$ carrying $\mathrm{Tn} 5393 \mathrm{w} / \mathrm{str} A-$ str $B$ genes & 8 \\
\hline BCN77 & $\mathrm{Sm}^{\mathrm{r}}$, chromosomal insertion of Tn5393 w/ strA-strB genes & 22 \\
\hline NY17.1 & $\mathrm{Sm}^{\mathrm{r}}$, isolated $11 / 2002$ & This study \\
\hline NY17.2 & $\mathrm{Sm}^{\mathrm{r}}$, isolated $11 / 2002$ & This study \\
\hline Ea110- & $\mathrm{Rf}^{\mathrm{r}}$, containing $\mathrm{pC} 9$ & 21 \\
\hline pC9 & 4.4-kb Pst I fragment from pEA29 cloned into pGEM3zft(+) & 21 \\
\hline
\end{tabular}

${ }^{\mathrm{a}} \mathrm{Rf}^{\mathrm{r}}$ and $\mathrm{Sm}^{\mathrm{r}}=$ resistant to rifampicin and streptomycin, respectively.

b Cornell University, Ithaca, NY.

Table 2. Polymerase chain reaction primers developed in this study

\begin{tabular}{llc}
\hline Gene & \multicolumn{1}{c}{ Primer } & Product size (bp) \\
\hline$r p s L$ & rpsL212-F: 5'-cgtacgcaaagttgcaaaaa-3' & \\
& rpsL212-R: 5'-ggatcaggatcacggagtgt-3' & 212 \\
$s t r A$ & strA406-F: 5' -tgactggttgctgtcagag-3' & \\
& strA406-R: 5'-cggtaagaagtcgggattga-3' & 406 \\
$s t r B$ & strB403-F: 5'-atcgctttgcagctttgttt-3' & \\
& strB403-R: 5'-cgttgctcetcttctccatc-3' & 403 \\
\hline
\end{tabular}


at $28^{\circ} \mathrm{C}$ and dilution plated on LB medium amended with rifampicin, streptomycin, or rifampicin plus streptomycin at $50 \mu \mathrm{g} / \mathrm{ml}$. Plates were incubated at $28^{\circ} \mathrm{C}$ and resultant colony growth on medium amended with both antibiotics signified bacterial conjugation. All isolates used in this experiment contained the ubiquitous nontransmissible plasmid pEA29; if the strA$s t r B$ resistance genes are located on plasmid pEA29 or inserted into the chromosome, no transfer of resistance would be observed.

Plasmid curing. The ubiquitous nontransmissible plasmid pEA29 was cured from E. amylovora isolates through incompatibility eviction assay previously described by McGhee and Jones (21). Plasmid curing was performed to determine the effect of pEA29 on streptomycin resistance. Plasmid pC9 (Ampr; Table 1), containing the pEA29 ori region, was electroporated into isolates NY17.1, NY17.2, CA11, and Ea273. Bacteria were grown on LB medium amended with ampicillin at 50 $\mu \mathrm{g} / \mathrm{ml}$ to select for $\mathrm{pC}$. Plasmid pEA29 eviction was verified using the pEA29specific primers A and B (2) compared with E. amylovora chromosomal primers AJ245 and AJ246 (16). PCR reactions, 50 $\mu \mathrm{l}$ in total volume, were carried out using $0.4 \mu \mathrm{M}$ either $\mathrm{A}$ and $\mathrm{B}, \mathrm{AJ} 245$ and $\mathrm{AJ} 246$, with $12.5 \mathrm{mM} \mathrm{MgCl}, 5 \mu \mathrm{l}$ of PCR Reaction Buffer (Promega Corp.), $0.1 \mathrm{mM}$ dNTP, 0.625 units of Taq DNA Polymerase (Promega Corp.), and $10 \mu \mathrm{l}$ of bacterial sample. Plasmid-cured isolates were dilution plated on LB medium amended with ampicillin, streptomycin, or ampicillin and streptomycin at $50 \mu \mathrm{g} / \mathrm{ml}$.

\section{RESULTS}

Resistance screening and pathogenicity assay. Between 2002 and 2006, 99 fire blight samples were submitted and processed at the New York State Agricultural Experiment Station in Geneva. In all, 316 isolations were made, and 249 singlecolony isolates of E. amylovora were screened for resistance to streptomycin. In August 2002, streptomycin-resistant isolates were recovered from symptomatic apple shoots (cv. Idared) collected from a newly planted orchard in Wayne County. Initial sampling occurred on 29 July 2002. Subsequent sampling was conducted on 21 November 2002 and 7 May 2003 to con- firm the presence of streptomycin-resistant E. amylovora. Nine single-colony isolates were confirmed as E. amylovora and found to be resistant to streptomycin at 100 $\mu \mathrm{g} / \mathrm{ml}$; no clear zone of inhibition was produced in response to streptomycin at this concentration after 24 or $48 \mathrm{~h}$. A representative streptomycin-resistant isolate was cataloged as E. amylovora NY17.1. Streptomycin-resistant E. amylovora also was recovered from an orchard located approximately $4.8 \mathrm{~km}$ from the original logued as NY17.2. Streptomycin-resistant isolates were pathogenic on both immature pear fruit and apple seedlings (data not shown). No resistant isolates were identified in orchards surrounding the two suspect plantings. Investigation revealed that Idared trees planted at both orchards originated from the same nursery shipment. Resistance was confirmed and trees at both orchard sites were removed in the winter of 2003-04. Between 2003 and 2006, no new streptomycin-resistant isolates were identified in New York.

rps $L$ gene sequencing. Comparison of the 212-bp sequences amplified from the rpsL gene verified a highly conserved region across all six isolates of E. amylovora. Two different single-base-pair mutasampling site on 21 November 2002, cata-

tions were observed in the streptomycinresistant isolates CFBP1376str and Ea88100 (Table 3). CFBP1376str was shown to have a deleterious mutation, lysine to threonine, whereas strain Ea88-100 was shown to have a persistent mutation, lysine to arginine. New York isolates NY17.1 and NY17.2 and streptomycin-resistant strain CA11 were identical to the susceptible strain Ea273 at codon 43 of the $r s p L$ gene coding for the wild-type amino acid lysine (AAA).

strA-strB gene identification. strA and $s t r B$ gene primers amplified $406-$ and 403 bp regions of the $s t r A$ and $s t r B$ genes from both streptomycin-resistant isolates from New York. Band size was consistent with CA11, which is positive for the $\operatorname{strA-strB}$ gene cluster (Fig. 1). No amplification occurred in isolates with chromosomal resistance conferred by mutation of the $r p s L$ gene or in the wild-type streptomycin-sensitive strain. Sequence results confirmed the identity and conserved nature of the $s t r A$ and $s t r B$ genes previously described from E. amylovora.

Plasmid transfer. Plasmid transfer of streptomycin resistance was observed when CA11 was utilized as the donor stain but not with the wild-type strain Ea273. CA11 contains the $s t r A-s t r B$ gene pair on

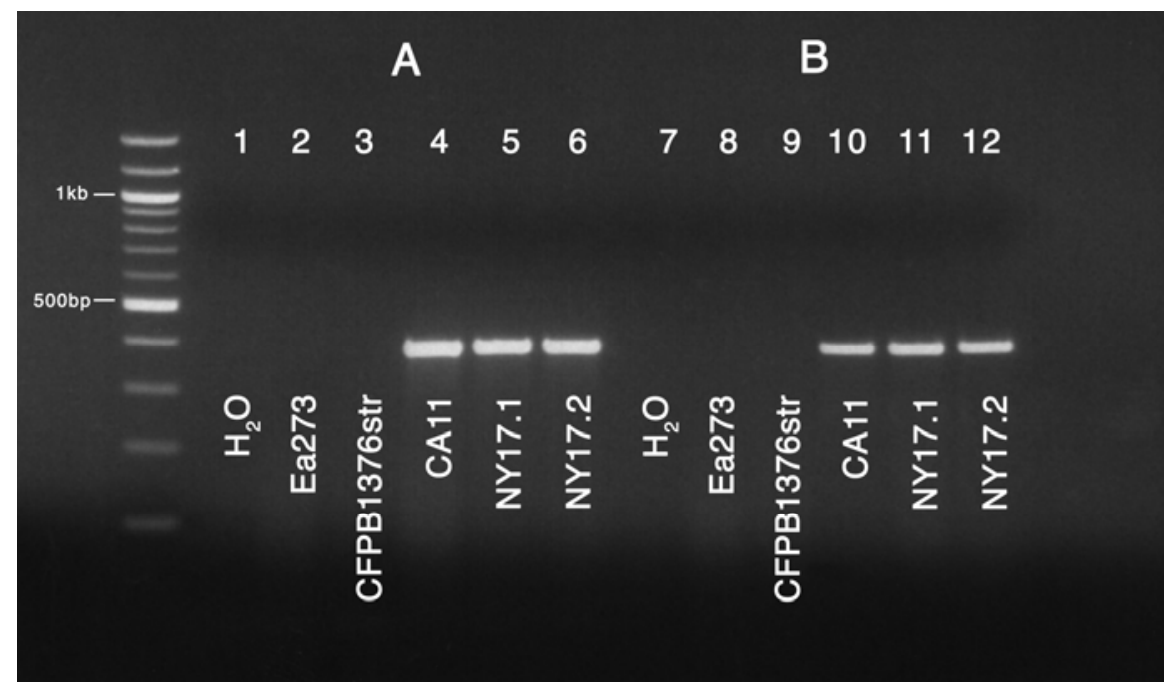

Fig. 1. Agarose gel depicting amplification products from a polymerase chain reaction analysis of Erwinia amylovora reference isolates and new streptomycin-resistant isolates using primers strA406F\&R and strB403-F\&R based on 406- and 403-bp internal fragments of the A strA and B strB genes, respectively. Lanes 1 and 7, water; lanes 2 and 8, strain Ea273; lanes 3 and 9, CFPB1376str; lanes 4 and 10, CA11; lanes 5 and 11, NY17.1; and lanes 6 and 12, NY17.2.

Table 3. Sequence comparison of rpsL gene from streptomycin-sensitive and -resistant isolates of Erwinia amylovora

\begin{tabular}{lcc}
\hline Strain & Sm $^{\text {ra }}$ & Sequence \\
\hline Ea273 & - & CTCGTGTGTACACGACTACCCCTAAAAAACCGAACTCCGCACTGCGT \\
CFBP1376str & CTCGTGTGTACACGACTACCCCTACAAAACCGAACTCCGCACTGCGT \\
CA11 & + & CTCGTGTGTACACGACTACCCCTAAAAAACCGAACTCCGCACTGCGT \\
Ea88-100 & + & CTCGTGTGTACACGACTACCCCTAGAAAACCGAACTCCGCACTGCGT \\
NY17.1 & + & CTCGTGTGTACACGACTACCCCTAAAAAACCGAACTCCGCACTGCGT \\
NY17.2 & + & CTCGTGTGTACACGACTACCCCTAAAAAACCGAACTCCGCACTGCGT \\
\hline
\end{tabular}

a Absence (-) or presence (+) of streptomycin resistance.

${ }^{\mathrm{b}}$ Deleterious mutation, lysine (AAA) to threonine (ACA), results in unstable streptomycin resistance, which retards colony growth.

c Persistent mutation, lysine (AAA) to arginine (AGA), results in stable streptomycin resistance. 
conjugative plasmid pEa34 (7; Table 4). Growth of CA11 on media containing streptomycin exceeded growth on medium harboring both antibiotics but frequency of plasmid transfer remained high. Growth of the recipient strain CU0380 remained constant in all matings and did not contribute to differences in plasmid transfer. No transfer of resistance was observed between CU0380 and either New York isolate NY17.1 or NY17.2. No spontaneous mutations conferring either streptomycin or rifampicin resistance were observed during the course of the experiment. Experiments were repeated with similar results.

Plasmid curing. Plasmid pEA29 was evicted from isolates Ea273, NY17.1, and NY17.2 through the introduction of plasmid pC9. Growth on medium amended with ampicillin verified the presence of pC9 in all bacterial strains. Plasmid eviction was verified by the absence of a $1-\mathrm{kb}$ fragment from pEA29 as determined by PCR (data not shown). Complete eviction of pEA29 was not achieved for streptomycin-resistant strain CA11, even in the presence of $\mathrm{pC} 9$, verified by resistance to ampicillin at $50 \mu \mathrm{g} / \mathrm{ml}$ (Table 5). Based on the nature of streptomycin resistance in CA11 $(9,10)$ results were not influenced by incomplete eviction of pEA29. Results clearly demonstrated that isolates NY17.1 and NY17.2 lost the ability to grow on streptomycin-amended medium after eviction of plasmid pEA29 (Table 5). No spontaneous mutations conferring either streptomycin or ampicillin resistance were observed during the course of the experiment. Experiments were repeated with similar results.

\section{DISCUSSION}

In 2002 and 2003, resistant isolates of $E$. amylovora were isolated from two neighboring orchards in Wayne County. New York isolates were found to be highly resistant to streptomycin without losing pathogenicity. These results constitute the first authenticated report of streptomycinresistant E. amylovora in New York. In 2003 , both orchards were removed in an effort to prevent the establishment of streptomycin-resistant bacteria. Beyond the two initial plantings sampled in 2002, no streptomycin-resistant E. amylovora has been identified in New York since 2003. Early identification and prompt orchard eradiation can be attributed in halting the spread of streptomycin resistance and forestalling the loss of streptomycin for future control of fire blight.

Since the discovery of streptomycinresistant E. amylovora in California in 1971, antibiotic usage in apple and pear regions has been reduced dramatically. Reduction in the number of antibiotic applications has been proposed as the main strategy to delay antibiotic resistance development $(23,25)$. Streptomycin usage in New York State, however, historically has been modest compared with usage in California and Michigan, where resistance was documented in the early 1970s and 1990s, respectively. Moller et al. (25) suggested that, with continued reliance on streptomycin, resistance development is inevitable due to constant mutation and selection in bacterial populations. Although reduction in antibiotic usage is necessary to maintain the effectiveness of streptomycin, there are other means by which resistant bacteria become established in new areas.

Over the past 200 years, fire blight, originally identified in the Hudson Valley, New York, has been unintentionally disseminated throughout the world via the movement of infected plant material (4). Introduction of bacteria on nursery stock poses a great risk for regions without endemic fire blight. Potential impact on apple production is magnified by the probability of importing streptomycin-resistant E. amylovora. With regard to the streptomycin-resistant isolates from New York, evidence supports the theory that trees were infected with E. amylovora resistant to streptomycin prior to planting. Resistant isolates from Wayne County were identified in orchards that had been planted the previous year and had yet to flower. Fire blight cankers in these plantings were considerable despite the young age of the planting and limited exposure to external sources of E. amylovora, which suggested prior infection. Furthermore, only one of the plantings had been treated with streptomycin prior to detection of resistant bacteria. Planting material in both orchards originated from the same nursery located in southwestern Michigan, a region where streptomycin-resistant E. amylovora had been described previously (7-10). Trees

Table 4. Resistance profile of recipient strain CU0380 (rifampicin resistant; $\mathrm{Rf}^{\mathrm{r}}$ ) after bacterial conjugation with streptomycin-resistant $\left(\mathrm{Sm}^{\mathrm{r}}\right)$ donor isolates CFBP1376str, CA11, NY17.1, and NY17.2

\begin{tabular}{llccc}
\hline & & \multicolumn{3}{c}{ Colony development $(\mathbf{C F U} / \mathbf{m l})^{\mathbf{a}}$} \\
\cline { 3 - 5 } Donor strain & Recipient & Sm & Rf & Transconjugants Sm with Rf $^{\mathbf{b}}$ \\
\hline CFBP1376str & CU0380 & $5.0 \times 10^{7}$ & $3.0 \times 10^{7}$ & 0 \\
CA11 & CU0380 & $7.0 \times 10^{7}$ & $3.8 \times 10^{6}$ & $1.6 \times 10^{6}$ \\
NY17.1 & CU0380 & $1.6 \times 10^{8}$ & $1.0 \times 10^{7}$ & 0 \\
NY17.2 & CU0380 & $2.6 \times 10^{7}$ & $1.3 \times 10^{7}$ & 0 \\
\hline
\end{tabular}

${ }^{a}$ Transconjugant growth signifies transfer of streptomycin resistance plasmid.

${ }^{b}$ Bacterial growth measured as $\mathrm{CFU} / \mathrm{ml}$ on media supplemented with either Sm, Rf, or a combination of both at $50 \mu \mathrm{g} / \mathrm{ml}$.

Table 5. Resistance profile of isolates cured of plasmid pEA29 through incompatibility eviction assay using plasmid pC9

\begin{tabular}{lllll}
\hline & \multicolumn{5}{c}{ Colony development $(\mathbf{C F U} / \mathbf{m l})^{\mathbf{a}}$} \\
\cline { 2 - 5 } Strain $^{\mathbf{b}}$ & LB $^{\mathbf{c}}$ & $\mathbf{A m p}$ & $\mathbf{S m}$ & $\mathbf{A m p}+\mathbf{S m}$ \\
\hline Ea273 & $8.3 \times 10^{10}$ & $6.83 \times 10^{10}$ & 0 & 0 \\
CA11 & $1.9 \times 10^{8}$ & $1.27 \times 10^{8}$ & $1.17 \times 10^{8}$ & $3.67 \times 10^{7}$ \\
NY17.1 & $8.0 \times 10^{9}$ & $9.83 \times 10^{8}$ & 0 & 0 \\
NY17.2 & $7.33 \times 10^{9}$ & $3.03 \times 10^{9}$ & 0 & 0 \\
\hline
\end{tabular}

a Ampicillin (Amp) resistance signifies acquisition of the selective plasmid $\mathrm{pC} 9 ; \mathrm{Sm}=$ streptomycin.

${ }^{\mathrm{b}}$ Designates isolates cured of plasmid pEA29 by incompatibility eviction assay.

${ }^{\mathrm{c}}$ Luria-Bertani.

${ }^{d}$ CA11 demonstrated incomplete eviction of pEA29; growth of bacteria in culture was inhibited. 
documented $(11,23,33)$. Our findings, although inconclusive, do address the potential for infected nursery material to serve as a vehicle to spread resistant bacterial populations.

Alternate materials for control of fire blight have been investigated; however, nothing has proven to be as effective or as durable as streptomycin. Oxytetracyline has been approved for use on pear and is available on a limited basis for apple in California and Michigan, where streptomycin-resistant isolates of E. amylovora have been identified. Oxytetracycline, however, is not as effective as streptomycin on streptomycin-sensitive isolates and only outperforms streptomycin in areas where streptomycin resistance occurs $(23,36)$. In Israel, oxolinic acid is used to control fire blight but resistant isolates were identified only 1 year after commercial release (18). New antibiotics, such as gentamicin (Agry-Gent; Gowan Co. LLC, Yuma AZ) and kasugamycin (Kasumin; Arysta Lifescience Corp., Tokyo) are being evaluated for the control of fire blight, with some promising results (36). Unfortunately, although effective, concern over the spread of antibiotic resistance to human pathogens has impeded the registration of new antibiotics for agricultural use (23). Streptomycin is the most effective antibiotic for use on apple and is likely to remain as such; therefore, it is imperative to identify cases of antibiotic resistance early, before bacterial populations become established.

\section{ACKNOWLEDGMENTS}

We thank D. Rosenberger, K. Iungerman, and J. Carroll for collection and submission of fire blight samples; and G. Sundin and G. McGhee for additional bacterial isolates and plasmids used in this study.

\section{LITERATURE CITED}

1. Beer, S. V., and Norelli, J. L. 1976. Streptomycin resistant Erwinia amylovora not found in western New York pear and apple orchards. Plant Dis. Rep. 60:624-626.

2. Bereswill, S., Pahl, A., Bellemann, P., Zeller, W., and Geider, K. 1992. Sensitive and species specific detection of Erwinia amylovora by polymerase chain reaction analysis. Appl. Environ. Microbiol. 58:3522-3526.

3. Billing, E., Crosse, J. E., and Garrett, C. U. E. 1960. Laboratory diagnosis of fire blight and bacterial blossom blight of pear. Plant Pathol. 9:19-25.

4. Bonn, W. G., and van der Zwet, T. 2000. Pages 37-53 in: Fire Blight: the Disease and Its Causative Agent, Erwinia amylovora. J. L. Vanneste, ed. CAB International. Wallingford, UK.

5. Burr, T. J., Norelli, J. L., Katz, B., Wilcox, W. F., and Hoying, S. A. 1988. Streptomycin resistance of Pseudomonas syringae pv. papulans in apple orchards and its association with a conjugative plasmid. Phytopathology 78:410413.

6. Burr, T. J., Norelli, J. L., Reid, C. L., Capron, L. K., Nelson, L. S., Aldwinckle, H. S., and Wilcox, W. F. 1993. Streptomycin resistant bacteria associated with fire blight infections. Plant Dis. 77:63-66.

7. Chiou, C. S., and Jones, A. L. 1991. The analysis of plasmid-mediated streptomycin resistance in Erwinia amylovora. Phytopathology 81:710-714.

8. Chiou, C. S., and Jones, A. L. 1993. Nucleotide-sequence analysis of a transposon (Tn5393) carrying streptomycin resistance genes in Erwinia amylovora and other gramnegative bacteria. J. Bacteriol. 175:732-740.

9. Chiou, C. S., and Jones, A. L. 1995. Expression and identification of the strA-strB gene pair from streptomycin-resistant Erwinia amylovora. Gene 152:47-51.

10. Chiou, C. S., and Jones, A. L. 1995. Molecular analysis of high-level streptomycin resistance in Erwinia amylovora. Phytopathology 85:324-328.

11. Coyier, D. L., and Covey, R. P. 1975. Tolerance of Erwinia amylovora to streptomycin sulfate in Oregon and Washington. Plant Dis. Rep. 59:849-852.

12. Crosse, J. E., and Goodman, R. N. 1973. A selective medium for and a definitive colony characteristic of Erwinia amylovora. Phytopathology 63:1425-1426.

13. Huang, T. C., and Burr, T. J. 1999. Characterization of plasmids that encode streptomycinresistance in bacterial epiphytes of apple. J. Appl. Microbiol. 86:741-751.

14. Jock, S., Donat, V., Lopez, M. M., Bazzi, C., and Geider, K. 2002. Following spread of fire blight in Western, Central, and Southern Europe by molecular differentiation of Erwinia amylovora isolates with PFGE analysis. Environ. Microbiol. 4:106-114.

15. Jock, S., and Geider, K. 2004. Molecular differentiation of Erwinia amylovora isolates from North America and of two Asian pear pathogens by analyses of PFGE patterns and $h r p N$ genes. Environ. Microbiol. 6:480-490.

16. Jones, A. L., and Geider, K. 2001. Gramnegative bacteria, Erwinia amylovora group. Pages 40-45 in: Laboratory Guide for Identification of Plant Pathogenic Bacteria, 3rd ed. N. W. Schaad, J. B. Jones, and W. Chun, eds. American Phytopathological Society, St. Paul, $\mathrm{MN}$.

17. Jones, A. L., and McGhee, G. C. 2001. Plasmids pEa29 and pEa34 in Erwinia amylovora are unrelated. Microbiology 147:2632-2633.

18. Kleitman, F., Shtienberg, D., Blachinsky, D., Oppenheim, D., Zilberstaine, M., Dror, O., and Manulis, S. 2005. Erwinia amylovora populations resistant to oxolinic acid in Israel: prevalence, persistence, and fitness. Plant Pathol. 54:108-115.

19. Longstroth, M. 2000. The fire blight epidemic in southwestern Michigan 2000. Michigan State University Extension, published online. http://www.canr.msu.edu/vanburen/fb2000.htm

20. Loper, J. E., Henkels, M. D., Roberts, R. G., Grove, G. G., Willett, M. J., and Smith, T. J. 1991. Evaluation of streptomycin, oxytetracycline, and copper resistance of Erwinia amylovora isolated from pear orchards in Washington State. Plant Dis. 75:287-290.

21. McGhee, G. C., and Jones, A. L. 2000. Complete nucleotide sequence of ubiquitous plasmid pEA29 from Erwinia amylovora strain Ea88: gene organization and intraspecies variation. Appl. Environ. Microbiol. 66:4897-4907.

22. McManus, P. S., and Jones, A. L. 1994. Epidemiology and genetic analysis of streptomycin resistant Erwinia amylovora from Michigan and evaluation of oxytetracycline for control. Phytopathology 84:627-633.

23. McManus, P. S., Stockwell, V. O., Sundin, G. W., and Jones, A. L. 2002. Antibiotic use in plant agriculture. Annu. Rev. Phytopathol. 40:443-465.

24. Miller, T. D., and Schroth, M. N. 1972. Monitoring epiphytic population of Erwinia amylovora on pear with a selective medium. Phytopathology 62:1175-1182.

25. Moller, W., Schroth, M., and Thompson, S. V. 1981. The scenario of fire blight and streptomycin resistance. Plant Dis. 65:563-568.

26. Momol, M. T., Momol, E. A., Lamboy, W. F., Norelli, J. L., Beer, S. V., and Aldwinckle, H. S. 1997. Characterization of Erwinia amylovora isolates using random amplified polymorphic DNA fragments (RAPDs). J. Appl. Microbiol. 82:389-398.

27. Norelli, J. L., Aldwinckle, H. S., and Beer, S. V. 1984. Differential host $\times$ pathogen interactions among cultivars of apple and isolates of Erwinia amylovora. Phytopathology 74:136139.

28. Norelli, J. L., Burr, T. J., Locicero, A. M., Gilbert, M. T., and Katz, B. H. 1991. Homologous streptomycin resistance gene present among diverse gram-negative bacteria in New York State apple orchards. Appl. Environ. Microbiol. 57:486-491.

29. Norelli, J. L., Holleran, H. T., Johnson, W. C., Robinson, T. L., and Aldwinckle, H. S. 2003. Resistance of Geneva and other apple rootstocks to Erwinia amylovora. Plant Dis. 87:2632.

30. Palmer, E. L., Teviotdale, B. L., and Jones, A. L. 1997. A relative of the broad-host-range plasmid RSF1010 detected in Erwinia amylovora. Appl. Environ. Microbiol. 63:4604-4607.

31. Paulin, J. P., and Samson, R. 1973. Le feu bacterien en France. II. Caractres des souches d'Erwinia amylovora isolés du foyer francobelge. Ann. Phytopathol. 5:389-397.

32. Quamme, H. A., and Bonn, W. G. 1981. Virulence of Erwinia amylovora and its influence on the determination of fire blight resistance of pear cultivars and seedlings. Can. J. Plant Pathol. 3:187-190.

33. Schroth, M. N., Thomson, S. V., and Moller, W. J. 1979. Streptomycin resistance in Erwinia amylovora. Phytopathology 69:565-568.

34. Shaffer, W. H., and Goodman, R. N. 1985. Appearance of streptomycin-resistant Erwinia amylovora in Missouri apple orchards. Phytopathology 75:1281-1281.

35. Sholberg, P. L., Bedford, K. E., Haag, P., and Randal, P. 2001. Survey of Erwinia amylovora isolates from British Columbia for resistance to bactericides and virulence on apple. Can. J. Plant Pathol. 23:60-67.

36. Shtienberg D., Zilberstaine, M., Oppenheim, D., Herzog, Z., Manulis, S., Shwartz, H., and Kritzman, G. 2001. Efficacy of oxolinic acid and other bactericides in suppression of $\mathrm{Er}$ winia amylovora in pear orchards in Israel. Phytoparasitica 29:143-154.

37. Sobiczewski, P., Chiou, C. S., and Jones, A. L. 1991. Streptomycin resistant epiphytic bacteria with homologous DNA for streptomycin resistance in Michigan apple orchards. Plant Dis. 75:1110-1113.

38. Sundin, G. W. 2002. Distinct recent lineages of the $\operatorname{strA}$-strB streptomycin-resistance genes in clinical and environmental bacteria. Curr. Microbiol. 45:63-69.

39. Thomson S. V., Gouk, S. C., Vanneste, J. L., Hale, C. N., and Clark, R. G. 1993. The presence of streptomycin resistant isolates of $\mathrm{Er}$ winia amylovora in New Zealand. Acta Hortic. 338:223-230.

40. Vanneste, J. L. 2000. Page 1-6 in: Fire Blight: the Disease and Its Causative Agent, Erwinia amylovora. J. L. Vanneste, ed. CAB International, Wallingford, UK. 